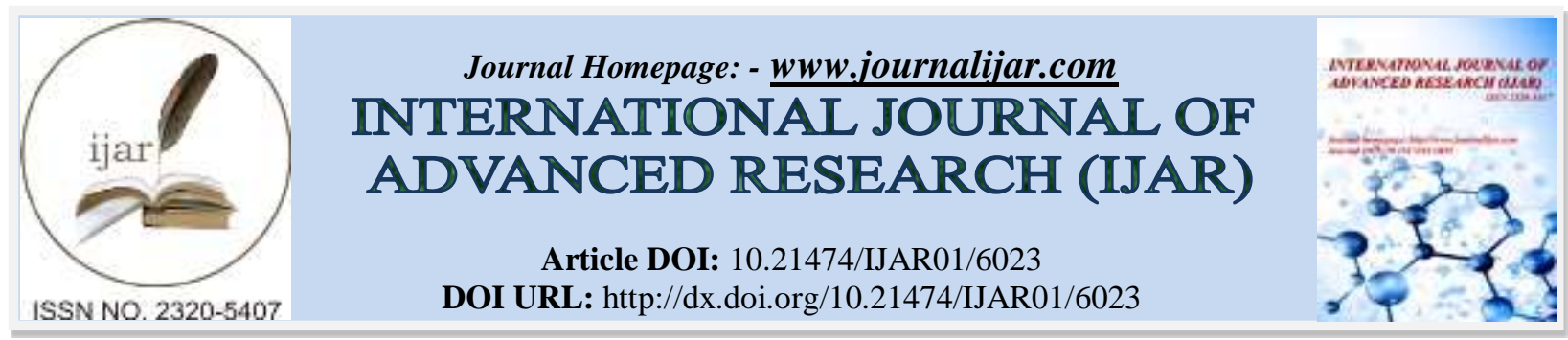

RESEARCH ARTICLE

\title{
GROWING ROLE OF SOCIAL MEDIA IN INDIAN SOCIETY :NEED FOR ITS CAUTIOUS ADOPTION AS A FORCE ENHANCER IN THE ARMED FORCES.
}

\author{
Rajneesh Kumar and Dr. Shalini Saxena.
}

\section{Manuscript Info}

(.........................

Manuscript History

Received: 10 October 2017

Final Accepted: 12 November 2017

Published: December 2017
Abstract

Copy Right, IJAR, 2017,. All rights reserved.

\section{Introduction:-}

Conservatively the social media emerged as a platform for social interaction and gradually progressed to transform itself into an effective tool of e-governance .In fact its utility depends upon the manner in which we use it constructively .Recent revolutions in the field of Information and Communication Technology )ICT (have literally shrunk the universe technologically and demonstrated our global strategic reach .These revolutions have led to a simultaneous upsurge in the usage of Smartphones and Tablets )also called the New Media devices (flanking the enhanced utilisation of social media platforms by the young Indian generation .

Presently the cost of Smartphones-which are considered to be the latest and most commonly available social media platform in vogue -has witnessed a sharp decline during the period from 2010-2015. The latest models of internet capable smartphones are today easily available at affordable prices commercially off the shelf .

The armed forces personnel-officers as well as men -hail from a diversified socio-economic \& cultural milieu .As members of the armed forces, their exposure to the better lifestyle supported by adequate financial backing inspires the young officers and men )not to exclude their families (to lead a contemporary lifestyle. Today not only the armed forces personnel, but their families also are found to be getting increasingly engrossed with the most modern electronic communication gadgets and striving to have an enhanced online presence.

However, notwithstanding the popularity of social media hosted on new media platforms and a zest to lead a contemporary lifestyle by their members, the armed forces do have a valid concern i.e .safeguarding the vital information and preventing its inadvertent slippage into undesirable hands .

Communication plays a vital role in conduct of operations in the armed forces .Infact the current concept of warfare has transformed itself into net centric warfare with improved connectivity and has emerged as a crucial force enhancer in the military science today .

\section{Imprint of Social Media on Human Life:-}

India had approximately 60 million internet users in 2009 .The number has risen to about 350 million today with around 150 million internet users belonging to rural India .As per rough estimates, the queries in local language have increased manifold in the past $1 \frac{1}{2}$ years with queries in Hindi language constantly increasing with every passing 
day .The social media on New Media platforms has impacted the human life in an unprecedented way .Today, India has approximately 450 million internet users out of which about $50 \%$ are active on social media.

Today the elements of collectivism, connectivity and cohesion form the hallmark of social media management in India .In context of the armed forces, we are witness to the online presence of friends, family members, commanders and all ranks on the same social media platform .

The use of social media has come to influence the minds also of our children immensely today as most of our family members especially the teenagers are found deeply engrossed in Facebook and Whatsapp .This has also impacted the adults in a major way as checking up Whatsapp and Facebook on our smartphones first thing on waking up in the morning is a commonest phenomenon among all of us .

This apart, the Facebook and Whatsapp have also come to be used increasingly for commercial purposes in India with many aspiring entrepreneurs launching their publicity campaigns largely on these platforms .The members of the armed forces being a part of same social milieu, cannot ignore the ease of satisfying our daily needs that the ecommerce on social media offers.

\section{Threats to Armed Forces from Social Media:-}

However, notwithstanding the above in favour of social media, the picture is not as rosy as we are sometimes made to believe .There is no doubt that the knowledge-information combine makes us wise \& informed citizens but certain degree of caution is definitely the prudent need of the hour. This is backed with the fear that if not handled efficiently, the social media has potential to play havoc. While there is every chance of inadvertent leakage of vital information, a viral video on social media site has strong potential of affecting our mind .This also sometimes leads to law and order issues .An example of this was the recent case of exodus of many students and working professionals belonging to North East from the IT hub of Bangalore as a result of malicious propaganda carried out on electronic media by some undesirable elements .

The experience substantiates the tremendous dividends offered by the electronic media in terms of knowledge, ease of governance, convenience and at the same time threats of varying magnitude .It assumes even greater significance now with the change in the nature of modern warfare .We have reasons to believe that today's war is going to be largely net-centric and will be fought through internet with all the essential services i.e .communication, weaponry as well as banking and technology etc connected electronically .

Visualised in this way, internet becomes a threat in the hands of adversary in face of a declared as well as undeclared war with operational security practically getting compromised on social media .For example, in Afghanistan, the pictures of four Apache helicopters parked in a secluded place was innocently clicked by some people and innocuously uploaded on social media .Soon these pictures were noticed and the aircraft were destroyed by the rebels .

Geo tagging and location features become latent threat and in fact, a number of social media platforms provide facility of geo tagging on Smartphones which actually has the capability of providing accurate contours of the intended target to the enemy .

Spreading malicious propaganda through social media is a strong weapon of psychological operations )psy-ops (or psychological warfare )psy-war .(The forces inimical to the integrity of the country rooted into various corners across the nation are today using social media on a large scale for dissemination of malicious propaganda with an aim of polluting the minds and subverting the morale of Indian populace. There is no doubt that social media if not handled responsibly and professionally, stands the risk of embarrassing the nation besides endangering its security at large .

The threats from social media amount to infringement of Individual Privacy .The activity on the profile of an individual in the form of posts, comments and messages posted on social media platforms with feeble security protocols or incorrect configuration of privacy settings of individual accounts may lead to unauthorised access through malware leading to compromised individual privacy . 
The individual social media account also becomes vulnerable to victimisation by anti-national elements as far as access to their personal webpage, profiles, pictures, and messages is concerned with the sole purpose of identifying soft targets which are then befriended followed by exploitation due to their manifest weaknesses e.g .money, wine, women or others. Once trapped, the victim under threat has no choice but to reveal sensitive information and automatically stands graduated into spying and seditious activities .Honey trap using morphed pictures of attractive females with seemingly authentic data on social media platforms is followed by blackmail . The Honey trap then leads to trapping and compelling the victim to divulge classified information. Another weapon of misuse of social media is through intimidation wherein the derogatory /objectionable messages with morphed pictures of victim are used to threaten and blackmail him or her for sexual favours. Once the victim is in the net, the stalker often threatens to post the morphed pictures online if one doesn't give in to the lascivious demands.

There are also threats to the Organisation arising from misuse of social media . Whenever any individual member of an organisation is trapped consequent upon careless usage of social media, the reputation of the organisation gets severely hit .Some of the threats experienced in the armed forces include leakage of Data .Innocuously circulated official data in the form of documents and snapshots of classified documents /presentations etc to support certain developments with regards to important activities e.g .pay commission award etc found circulating on social media is an example. Some of us are in the habit of blindly forwarding the posts as 'Forwarded as received' which leads to unintentional leakage of sensitive official information .This not only violates the Indian Official Secret Act 1923, but also passively helps in Intelligence gathering by our proclaimed national adversaries.This puts a speckle on the reputation of the organisation as many times, the posts are seen on social media which are against the service ethos and values cause embarrassment to the organization. Such posts not only demotivate and demoralize the personnel but also lead to the image of the armed forces getting tarnished in public eye .Another potent danger to the organisation from misuse of social media is in the form of an effective tool at the hands of enemy for Intelligence gathering through malware on social media apps installed on smartphone camera, GPS, contacts, data, etc .

Thirdly, a careless handling of social media by armed forces personnel and their families may pose greater threat to national security by means of messages of intimidating, provocative or threatening nature sent to the target to bully him or her .The young soldiers and teenagers stand a high risk in this category. This apart, the discount schemes and offers which many of us cherish and get easily carried away by, are used by spammers and criminals to lure us into the trap.With a casual click on the seemingly innocuous links provided with such offers, Trojans are installed which may hack vital information including our contacts and banking passwords or can even implant ransom-wares on the computers and information systems .These can also install viruses to continue hacking and extracting vital information even in future. The biggest fear of misuse of social media is perhaps is its misuse for supporting terrorist activities .Social media is susceptible to use by terrorist organizations as weapon for ideological radicalization, recruitment of cadres, communication among accomplices, and training of sympathisers and entrants .Terrorist groups also take advantage of social media to communicate with other cybercrime groups and collude with them for raising funds through social media. This apart, certain sensational pictures posted on social media in past validate the fright and panic it might create among the masses .

\section{Ensuring Safe and Secured Use of Social Media:-}

The cyber security consciousness is a macro and constant process and affects the modern life in a big way . Considering the national security needs, it should become the second habit among the personnel of the armed forces $\&$ their families .A number of guidelines and advisories being issued by the concerned echelons of armed forces from time to time have been useful. The experience tells us that it is always feasible and desirable to observe precautions to ensure safe and secured utilisation of social media by the armed forces personnel and their families . Adherence to some of the routine safety measures by the armed forces personnel and the members of their family as second habit would go a long way in preventing the misuse of social media .Few of such precautions that can be observed by the armed forces personnel in particular and their family members in general are listed as under -:

1. The serving armed forces personnel are bound by the organisational orders on cyber security .But at the same time they must also encourage their family members to appreciate the significance of cyber security and restrictions imposed through advisories and orders issued on the subject from time to time to ensure safety of personal information .

2. Abstain from bragging or flaunting their rank, position and appointment or places of posting through the photographs etc related thereto and posted on social media . 
3. Be cautious and not click on any pop-up menus or links provided in emails received from unknown senders/spammers. The emails received even from known senders should be verified first in case they carry any links.

4. Avoid flaunting or disclosing the identity as members of the armed forces fraternity on social media as far as possible .

5. NEVER upload any document or any photograph however interesting or attractive it may appear on social media . One should not post the photographs of armed forces personnel especially in service uniform .

6. Be meticulous and careful about the amount of personal details, photos and other information which one may decide to post on social media profile .

7. Carefully configure the Privacy settings on social media and review the same regularly .Keep changing the social media account password as frequently as required.

8. Ascertain and restrict the extent of viewing rights for friends, acquaintances and general public with respect to the information and photographs shared on social media .We must set the scope for viewing by "friends only."

9. Must avoid tweeting /commenting on sensitive current /important national issues having political /military / religious overtures on Facebook and Twitter, as it may embarrass the organisation to which they may belong .

10. Should not befriend anyone if the physical identity of such person cannot be verified .We must be highly selective about who we accept as friends on social network and by all means avoid in-person meetings with someone one may have only met online .

11. In the event of having any suspicion regarding the sites they might have visited or the person whom they may have shared information with, must make it a point to immediately report to their seniors about such an eventuality and initiate remedial actions as per the orders issued on the subject .

12. Must not announce the place of Posting or Temporary Duties or Detachment .Sometimes we do it purely unintentionally by requesting our friends and acquaintances on social media for accommodation or conveyance at newly posted stations or Temporary Duty or Detachment Units .

13. Must avoid discussing course schedules, contents and locations etc amongst the social media groups .

14. However euphoric it may appear, one should avoid uploading pictures of training days, reunion parties, or those showing in parties consuming liquor or smoking or in official parties or at casual get-togethers on social media, as far as possible.

15. Be aware of the provisions of IT Act 2000 and Official Secret Act 1923.

\section{Utilisation of Social Media as a Force Enhancer in the armed forces:-}

As stated above, the members of armed forces form a meaningful part of society and assume the irrefutable role of an active component thereof .There is therefore a need to use the social media platforms intelligently and more constructively and use it as a force enhancer to achieve enhanced performance by the armed forces .Presently the biggest problem of the armed forces is the negative propaganda especially while working in situations like Antiterrorist /Anti-Naxal and Counter Insurgency operations. There have been examples where the armed forces faced the mob fury for no fault of theirs .It is felt that an active online presence of armed forces on social media would greatly help in invalidating \& countering the negative propaganda being carried out by some vested interests against armed forces in real time by giving correct picture, ascertaining and instituting certain Dos and Don'ts for use of social media platforms. The effective use of social media and an increased online visibility of armed forces would greatly help in bailing them out of the avoidable appalling situations .This could also prove to be a big morale booster for the armed forces.

This apart, the achievements of the armed forces on professional and extramural fronts brought to the notice of general public by providing factual details )definitely unclassified( on social media would also help .These social media forums may also be used to highlight the achievements of the serving members as well as veterans of the armed forces in various fields viz. sports, research, social service, academics, governance \& public policy and so on . This would go a long way in improving the image of the armed forces in public eye .

Though already being done, the scope of constructive social interaction on social media platforms can be further widened in the armed forces fraternity with formation of larger social groups dedicated to the members belonging to one particular service/regiment/arm/stream etc on social media platforms e.g .Facebook, WhatsApp and Instagram etc .As stated above, some of these groups already exist on social media and can be used to manage social life among the families of the members of the armed forces .This would strengthen the bonhomie already existing among the armed forces personnel . 
Another constructive way of using social media in armed forces may be as communication force multiplier in the conduct of military operations .For this the Indian Air Force-as Net Centric Aerospace Force -has taken a lead by introducing an intranet within the organisation and also by providing a handheld extension thereof in the form of a cell phone on a secured network .The technology being followed is similar to the one used for civil communication network with additional reinforced precautions .The possibility of having a WhatsApp kind of social media platform on this secured network may further accentuate the true strategic autonomy that the IAF may desire to enjoy during operations .

With its unique people centric approach, the IAF has taken a lead also by introducing a professional blog on the secured intranet which has potential to pay rich dividends to the service personnel particularly the younger generation officers and air warriors by informally educating them on theoretical part of various professional concepts in an opinionated yet independent and informal manner .

This apart, the concept of a widespread tri-services operational communication network christened as Defence Communication Network )DCN (with capability to have nationwide inter-services operational communication has already taken birth post launching of a dedicated Defence Communication Satellite and the DCN having been formally inaugurated by the Hon'ble Raksha Mantri a few months ago .

The functionality of the DCN needs to be further expanded over a larger inter-services spectrum to cover even individual communication requirements of tri-service personnel and families perhaps with added facilities like secured handheld cell phones which the IAF has already introduced as a supplement to the already existing IAF intra-net .Having such inter-services communication facility on a secured and supervised network would also enable social interaction among members of armed forces on a variety of issues which may include even certain sensitive service specific issues e.g .welfare, pay \& pension award, service benefits etc which, despite several checks and balances being in place, are nowadays being increasingly discussed on Whatsapp and Facebook by some of the armed forces personnel and families. This renders the services related information indefensibly slipping in the hands of people who should not be privy to such details. This communication on a secured network would go a long way in encouraging communication among members of the organization in the inter-services environment and giving vent to their inner feelings in a monitored \& protected manner .

This apart, the online presence and visibility of armed forces would project an active image of the armed forces especially when we talk of the solemn role that the armed forces play during other than war or warlike situations like natural calamities and handling of law and order situations in aid to civil authority .The recent depiction of the contribution of the armed forces on social media while bringing succour to the members of public during Kedarnath crisis and during floods in Tamil Nadu, J\&K and Uttarakhand has accentuated the highly professional yet public friendly image of the armed forces .

The armed forces echelons dealing with Military History and Information Warfare )DIW (alongwith Media and PR should strive to undertake the arduous responsibility of projecting a positive online image of the armed forces in public eye through social media. The stories of valour and sacrifices made by the armed forces during operations and factual position existing on operational front with challenges faced while handling relief missions in times of natural crises and violent situations arising out of civil unrest etc .may be professionally covered with realistic details on social media sites e.g .Facebook etc .preferably under catchy titles like "Aapki kahaani hamari jubani" etc similar social media campaigns may be planned and hosted also on Twitter and Whatsapp with appropriate themes.

\section{Conclusion:-}

The popularity and reach of social media are increasing rapidly and it would only be prudent to use the social media technology to our advantage . While this is a valid proposition, the threats of social media to the armed forces personnel, to the organisation, and to the nation also need to be understood and appreciated by one and all .One has to understand that the comfort and convenience provided by social media can be enjoyed to the fullest only if we learn to carefully use the social media platforms with an added sense of responsibility .

The fact that in the interest of national security, the inadvertent slippage of sensitive information through social media cannot be afforded at any cost remains paramount. The awareness among the armed forces personnel in 
particular and their family members in general and an assurance of their wilful adherence to policies /procedures on the issue is therefore an inevitability to counter the social engineering constantly germinating into the system through escalating misuse of social media in the country .

While there is every requirement of using the social media responsibly and effectively for meeting the goals set by the armed forces in the professional and social realm, at the same time there is also an equally pressing need to use it for achieving the demonstrated operational efficiency and all the while doing so within the ambit of safety, responsibility and accountability. There is a definite need to strike a fine equilibrium between usage of social media and the security of information in the armed forces especially in face of present security scenario prevailing in the country .

It is undisputed that the social media is an emerging reality in the human life and the armed forces are not immune from its omnipresence. Therefore the desirable future utilisation of social media, particularly in respect of the armed forces is expected to be realised through a fine blend of the social, personal and professional commitment on part of each member of the armed forces. This becomes desirable especially considering the fact that the armed forces have conventionally \& traditionally been identified with their constant selfless service to the nation backed by a proven track record of high degree of commitment, dedication and unmatched professional standards since the times immemorial.

\section{References:-}

1. Cohen P .Stephen and Sunil Dasgupta .2013 .Arming without Aiming :India's Military Modernization . Washington D.C :.Brookings Institution Press .

2. Verma Bharat, Pandey B.K .and G.M .Hiranandani .2008 .Indian Armed Forces .New Delhi :Lancer Publishers \& Distributors .

3. Willems, W) .2014 .(Beyond Normative De-westernization :Examining Media Culture from the Vantage Point of the Global South. The Global South, 8)1(, 7-23 .

4. Ömür Harmanşah) .2015 .(ISIS, Heritage, and the Spectacles of Destruction in the Global Media. Near Eastern Archaeology, 78)3(, 170-177 .

5. Avle, S., \& Adunbi, O) .2015 .(Who's Freedom? Who's Information? :Discourses on Freedom of Information Policies. Journal of Information Policy, 5, 179-203 .

6. Laird, A).1921 .(The Persian Army and Tribute Lists in Herodotus. Classical Philology, 16)4(, 305-326. 